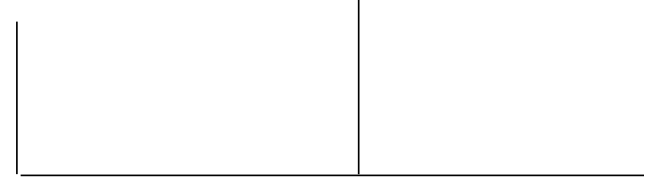

Rev. Latinoam. Psicopat. Fund., VIII, 1, 54-63

\title{
Ecology in the multiple contours of psychopathology*
}

Virginia Moreira

Based on the thought of Maurice Merleau-Ponty, I propose here a phenomenological understanding of psychopathology as mutually constituted along with ecology. I begin by describing the idea of multiple contours or a mundane understanding of psychopathology. I then consider ecology as part of these multiple contours. Finally I discuss how important it is for psychopathology to recognize its close link with ecology, as a way of overcoming the current epidemic of mental pathologies that afflict the contemporary world.

Key words: Psychopathology, ecology, mundane, Merleau-Ponty

* This article was originally presented at the 27th Annual Meeting of the Merleau-Ponty Circle : Ecology, Saint Louis, Missouri. U.S.A. (September 18 -22, 2002). 
Psychopathology [from psych(o)- + pathology] is defined as the pathology of mental illnesses or as the study of the causes and nature of mental illnesses. "Psych(o)-" comes from the Greek psyche, which means breath of life, or soul. The term can be found in words in Ancient Greek itself, such as psychagogue, and many others. Pathology refers to an affection, pain; "patho-" comes from the Greek pathos, which means "illness, passion, feeling". Both terms were introduced into international scientific language in the $19^{\text {th }}$ century (Cunha, 1997).

The psychological understanding of mental illness began when mental illness was first approached as an entity, by means of speculations of a philosophical nature, which was possible in a psychology as yet not individualized, expressed in terms of philosophy and medicine, and which was concerned with treating patients who were suffering from mental disturbances. Psychology in general, and traditional psychopathology, which developed subsequently within the framework of western thought, follow a Cartesian dualistic tradition, in which man has a within and a without, a social and an individual, an external and an internal, and so on. Studies within the framework of phenomenological psychiatric and psychological treatment show how psychopathology chooses as its object of study the within, the individual, the internal (Moreira, 2001; Tellenbach, 1967; Tatossian, 1997).

In this article I propose a phenomenological understanding of psychopathology as being mutually constituted with ecology, based on the thought of Maurice Merleau-Ponty. I begin by describing the idea of multiple contours for a worldly understanding of psychopathology. I then consider ecology as 
being part of these multiple contours, and finally discuss how important it is that psychopathology should recognize its close link with ecology, so that the current epidemic of mental pathologies afflicting the contemporary world can be overcome.

\section{The multiple contours of psychopathology}

In La doute de Cézanne Merleau-Ponty (1966) draws an analogy between his philosophy and Cézanne's paintings, showing how Cézanne mixes the real with reality, thus distorting reality. For Merleau-Ponty Cézanne's art, thus distorted and with multiple contours/outlines, is far more real than a photograph, for example, which claims to capture the exact reality of a particular moment. A photograph loses the movement, and separates the real from the imaginary, which makes it something fictitious and unreal, since reality, as perceived, is always in movement and is always distorted, especially as there is no clear dividing-line between the real and the imaginary (Moreira, 1998; 2001). In the words of Merleau-Ponty (1966) "Not to indicate any shape would be to deprive objects of their identity. To trace just a single outline sacrifices depth, that is, the dimension in which the thing is presented not as spread out before us but as an inexhaustible reality full of reserves" (p. 25).

The design thus results from the color, and not from a single line, and the world appears in its thickness as a dense mass, an organism composed of colors and lines. Color gives it texture and consistency through its multiple contours and not from a single, limiting line, in such a way that Cézanne's art would thus depict Merleau-Ponty's thought through the definitive destruction of dichotomies, through the recognition of the ambiguities inherent to human beings in the idea of multiple contours (Moreira, 1998; 2001).

In previous studies (ibid.) I used this idea of multiple contours for a worldly phenomenological understanding of psychopathology, proposing a view of the psychotic as someone without contours, or boundaries. What is experienced in psychosis, making an analogy with Cézanne's paintings, is pure color which is dispersed without boundaries, leading to much mental suffering. On the other hand, the contemporary neurotic (which would include the syndromes of the type which rigidify the personality, characterized by impulsive and anxious behavior)

1. An earlier version of this topic was presented in Moreira (2002). In this communication I repeat those ideas in order to introduce the ecological contour as part of this discussion. 
also do not experience a multiple contour or boundary with the world, but a rigid one, supposedly precise and defined, with little or no color, being just a pure line, with the same false precision which Merleau-Ponty ascribes to photography. In this view, the mentally ill would have a static existence, without movement, either because they find themselves without any contour with reality, or because they have rigid contours, living, in both cases, in a world devoid of color.

Among the many contours which make up the psychopathological framework in as dynamic and imprecise way as the paintings of Cézanne, the ecological boundary is a determining factor in ethiology, within the idea of a wordly psychopathology.

\section{Ecopsychology}

Ecology [from eco $+\log (0)+y]$ is defined as the part of biology which studies the relations between living beings and the environment in which they live, as well as their reciprocal influences. It is also understood as the branch of human sciences which studies the structure and development of human communities in their relations with the environment and their consequent adaptation to it, as well as new aspects which technological processes or systems of social organization may add to the living conditions of human beings. Ecology is thus the study of the equilibrium of the natural world and of human beings in this world.

Although ecology has traditionally been the object of concern of environmentalists and biologists, its second meaning in the framework of human sciences has been coming increasingly to the fore, on account of human interference in the ecology. This interference has been negative and destructive, leading to an increasing imbalance in the planet's ecology. In view of the fact that "we live on a planet that is deteriorating ecologically and inhabited by people who are psychologically troubled" (Brown, 1995, p. XIV), ecology has also come to be the focus of concern of Psychology, with even an area called Ecopsychology developing:

Ecopsychologists believe there is an emotional bond between human beings and the natural environment out of which we evolve (...) ecopsychology seeks to redefine sanity within an environmental context. It contends that seeking to heal the soul without reference to the ecological system of which we are an integral part is a form of self-destructive blindness. Ecopsychologists are drawing upon the ecological sciences to reexamine the human psyche as an integral part of the web of nature (ibid., p. XVI).

It is along this path, which criticizes the eminently individualistic mainstream psychology, that my proposal is located to also consider ecology as part of the 
multiple contours of psychopathology understood from a wordly perspective, in Merleau-Ponty's sense. In fact this is a matter of urgency on the part of mental health workers, since what we can observe is that, although every day new psychological, medical and psychopharmaceutical treatments appear for mental pathologies, the number of those afflicted continues to increase throughout the world; we are experiencing an epidemic of psychopathology in the contemporary world. Besides the ideological aspects which it presupposes, related to the question of biomedical power (Marsella \& Yamada, 2000), this epidemic is probably showing us that the individualistic approach of psychopathology is a failure.

\section{Psychopathology $x$ ecology}

With the purpose of contributing towards overcoming an individualistic approach, I shall now return to the understanding of psychopathology from the standpoint of the multiple contours in order to consider the relation between ecology and psychopathology, also with so many contours which interweave and are constituted mutually, just as in Cézanne's pictures. This view, proposed on the basis of Maurice Merleau-Ponty's thought aims to oppose the traditional individualistic view of psychopathology. In this way Merleau-Ponty's ideas, which are an attempt to overcome a dualistic form of thinking, can be of great use in considering psychopathology. We know that his philosophy stresses man's hereditary ties to the world and history, constantly criticizing those who claim to be "neutral scientists", seeing themselves as birds who form thoughts as they fly overhead. I have used his idea of human's rootedness to consider the rootedness of psychopathology, seeking to develop a clinical psychology which, rather than neutral, is ethical and committed to the ideal of a better world (Moreira, 2002).

The idea of a worldly psychopathology, which must thus include questions related to ecology, is based on the idea of the body as a "feeling thing", as subject-object. This recalls Merleau-Ponty's (1960) famous example of my right hand touching my left hand: "So I touch myself touching, my body achieves a 'kind of reflexion'. In oneself, for oneself, there is not just relation to a single sense of he who feels what he feels: the relation is inverted, the touched hand becomes the one that touches and I am obliged to say that the touching here is spread throughout the body, that the body is a 'feeling thing', 'subject-object' (p. 212). Striving continuously to overcome dichotomized thought and considering the human being as subject-object, Merleau-Ponty (1964) abolishes closed and absolute truths, in which there is the pure subject or object-world, "since our life has, in the astronomical sense of the term, an atmosphere; it is constantly 
surrounded by these mists which are called the world of senses or history" (p. 116). According to this line of reasoning, life, whether healthy or pathological, is permeated by the ecological world, as it continuously encounters ecological density.

Within this view of the body as subject-object, psychopathology comes up against experience. Merleau-Ponty (1960) states: "Experience in anthropology is our inserting social subjects in a whole in which the synthesis which our intelligence so laboriously seeks is already made, since we live in a single lifetime all the systems of which our culture is made" (p. 150). Among these various systems is ecology. Psychopathology is intrinsically constituted with ecology due to the fact that "the earth is the root of our history. Just as Noah's Ark carried everything that could remain that was alive and possible" (Merleau-Ponty, 1995, p. 111). Human experience is, then, the point of multiple intersection of the various systems - ecological, cultural, biological, historical, political, psychological, and so on - which interact with one another, merge and mix together. Insofar as a human beings are rooted in this world, everything which concerns the world concerns them too; there is no separation among the various systems, but multiple contours in constant movement. Thus it is, if we follow the French philosopher's line of thinking, that the earth is the root of history, and is also the root of psychopathology. The ecological imbalance of the earth constitutes the various mental imbalances which increase contemporary human suffering. Simultaneously, it is these same psychopathological processes that cause human beings to destroy the world in which they live, thereby destroying themselves. Let us now see how these processes occur.

\section{The notion of splitting}

To go a little more deeply into the question of the mutual constitution between psychopathology and ecology, it is useful to refer to the notion of splitting, which means division, separation, disintegration. We speak of a split personality in schizophrenia. Splitting is in fact a concept from early psychiatric and psychological treatment to describe dissociative processes that occur in mental illnesses, especially in psychoses. During the emergence of psychosis the patient becomes detached from reality, and comes to live just in a world of his own, cut off from the concrete world which he is in contact with. There thus occurs a very unusual form of living as a sentient body, in that this experience is created in a form apparently dissociated from the world of the senses and history, or, as I put it at the beginning, without contours with this world. 
Dissociated forms of behavior are increasingly common in postmodern societies, which lack integration between thinking, feeling and acting, which is evidently at the heart of the present epidemic of psychopathology, but also of ideological processes, as I have shown in previous studies (Moreira \& Sloan, 2002). For example, anxiety and compulsive disorders are characterized precisely by the automatization of actions without any type of reflection, and blocked communication will occur in all psychotic conditions, being present also in depression, in panic syndrome, in personality disorders and all the mental pathologies which are increasing in the modern world as a consequence of an individualistic culture with leads to loneliness, a lack of commitment to others, and narcissistic emptiness (Sloan,1966). But the same splitting that occurs in mental pathology occurs in ideological experiences, through the division between the awareness that something is wrong and behavior which denies this observation through another mechanism which idealizes something or someone, and which commonly derives from the residual idealization of paternal images (Moreira \& Sloan, 2002). What occurs both in psychopathological and ideological experience is a process of incongruence between thought, feeling and action, which leads to mental suffering and the disempowerment of the individual.

I think that this same notion of splitting is useful for describing the ecological experience of modern man. According to Metzner (1995),

(...) the entire culture of western industrial society is dissociated from its ecological substratum. It is not that our knowledge and understanding of the Earth's complex and delicate web of interdependence is vaguely and inchoately lodged in some forgotten basement of the psyche. We have the knowledge of our impact on the environment, we can perceive the pollution and degradation of the land, the waters, the air - but we do not attend to it, we do not connect that knowledge with other aspects of our total experience (p. 64-5).

I see ecological splitting occurring at the intersection of psychopathological splitting with ideological splitting. The countless destructive processes of our natural world obviously have something to do with a process of human death, of self-destruction, that continues every day, in a sick way, contrary to the principles of the preservation of life. On the other hand, we know that much of the process of ecological deterioration which we are experiencing has to do with ideological processes which are concerned exclusively with power and economic interests.

I see that what is at the heart of ecological splitting is, then, individualistic subjectivity, where man sees himself and takes responsibility just as a mere isolated individual, as if he were not capable or did not have the power to see himself as part of the world, and, therefore, be responsible for it. Thus the experience of global subjectivity, which includes ecology in its multiple 
boundaries, vanishes, succumbing to an individualistic subjectivity, which leads to psychopathology. We do not have an "ecological subjectivity", a construct proposed by Cavalcante Junior and Souza (2002), based on the observation that the survival of the human race depends on the existence of ecological subjects, responsible for their duty and authors of their history, constituted as a result of their ecological relations in the world and with the world. This why they propose a reaction to the ecological imbalance by means of processes of action and reflection in a school which proposes the authorship of the subject (Cavalcante Junior, 2001), which develops the construction and maintenance of an ecological subjectivity.

\section{Conclusion}

In conclusion, I would like to stress once more the valuable contribution that Merleau-Ponty's thought has given us, enabling us to widen the approach to psychopathology beyond the individual, into the world, since, as he reminds us, "this world which is not me and to which I am attached as intensely as I am to myself, is no more, in a sense, than an extension of my body; I have good reasons to say that I am the world" (Merleau-Ponty, 1964, p. 83).

Within this view psychopathology and ecology are interwoven, as part of the same fabric that composes the world and the human being. When we talk about the epidemic of contemporary psychopathology we are talking about the epidemic of processes of ecological destruction, both symptoms and processes of human disintegration.

Man is sick and thus destroys his world, but he is sick because the world that constitutes him is sick.

\section{References}

Brown, L. Ecopsychology and the environmental revolution. In: T. RoszaK; M. Gomes \& A. Kanner. Ecopsychology. San Francisco: Sierra Club Books, 1995.

Cavalcante Jr., F. Por uma escola do sujeito: o método (con)texto de letramentos múltiplos [For a school of the subject: the (con)text method of multiple literacies] Fortaleza: Edições Demócrito Rocha, 2001.

Souza, S. Por uma subjetivação ecológica [For an ecological subjectivization] Revista de Educação AEC, v. 31, n. 122, p. 41-7, 2002.

Lipovetski, G. La era del vacío. [The age of emptiness]. Barcelona: Anagrama, 1996. 
Marsella, A. \& Yamada, A. M. Culture and mental health: An introduction and overview of foundations, concepts and issues. In: I. Cuéllar \& F. Paniagua (Ed.). Handbook of multicultural mental health. London: Academic Press, 2000.

Merleau-Ponty, M. Signes. [Signs] Paris: Gallimard, 1960.

Le visible et l'invisible. [The visible and the invisible] Paris: Gallimard, 1964.

Sens et non sens [Sense and non-sense]. Paris: Nagel, 1966.

Nature. Paris: Seuil, 1995.

MetzNer, R. The psychopathology of the human-nature relationship. In: T. RoszaK; M. Gomes \& A. Kanner. Ecopsychology. San Francisco: Sierra Club Books, 1995.

Moreira, V. Una comprensión de la psicopatologia a partir de la fenomenologia de Merleau-Ponty [An understanding of psychopathology based on Merleau-Ponty's phenomenology]. Revista Chilena de Psicologia, v. 19, n. 1, p. 106-12, 1998.

Más allá de la persona: Hacia una psicoterapia fenomenológica mundana.

[Beyond the person: Towards a mundane phenomenological psychotherapy] Santiago: Universidad de Santiago de Chile, 2001.

Parte II: Psicopatologia Critica. In: V. Moreira \& T. Sloan. Personalidade, ideologia e psicopatologia crítica [Personality, Ideology and Critical Psychopathology]. São Paulo: Escuta, 2002.

Sloan, T. Personalidade, ideologia e psicopatologia crítica [Personality, Ideology and Critical Psychopathology]. São Paulo: Escuta, 2002.

SloAn, T. Damaged life: The Crisis of The Modern Psyche. New York: Routledge, 1996.

Tatossian, A. Psychiatrie Phénomenologique [Phenomenological psychiatry]. Paris: Acanthe, 1997.

Tellenbach, H. Estudios sobre la patogénesis de las perturbaciones psíquicas. [Studies in the pathogenesis of mental disturbances] Mexico: Fondo de Cultura Econômica, 1967.

\section{Acknowledgments}

I wish to thank Francisco Cavalcante Jr.

for his helpful comments on the first version of this chapter.

\section{Resumos}

Neste artigo proponho, baseada no pensamento de Merleau-Ponty, uma compreensão fenomenológica da psicopatologia enquanto mutuamente constituida com a ecologia. Inicialmente descrevo a idéia de múltiplos contornos ou uma compreensão 
mundana da psicopatologia. Em seguida considero a ecologia como sendo parte destes múltiplos contornos. Finalmente discuto a importância de que a psicopatologia reconheça seu intrínseco vínculo com a ecologia como parte de um possível caminho para a superação da atual epidemia de patologias mentais que afligem o mundo contemporâneo.

Palavras-chave: Psicopatologia, ecologia, mundano, Merleau-Ponty

En este artículo propongo, con base en el pensamiento de Merleau-Ponty, una comprensión fenomenológica de la psicopatología en tanto que mutuamente constituida con la ecología. De inicio describo la idea de los múltiplos contornos, o una comprensión mundana de la psicopatología. En seguido considero la ecología como formando parte de estos múltiplos contornos. Finalmente discuto la importancia de la psicopatología reconocer su intrínseco vínculo con la ecología como parte de un posible camino para la superación de la actual epidemia de patologías mentales que afligen el mundo contemporáneo.

Palabras claves: Psicopatología, ecología, mundano, Merleau-Ponty

Dans cet article je propose, sur la base de la pensée de Merleau-Ponty, une compréhension phénoménologique de la psychopathologie comme mutuellement constituée avec l'écologie. Je décris d'abord l'idée des contours multiples ou une compréhension mondaine de la psychopathologie. Ensuite je considère l'écologie comme faisant partie de ces contours multiples. Finalement, je discute l'importance pour la psychopathologie de reconnaître son lien intrinsèque avec l'écologie comme composante d'un possible chemin pour surmonter l'actuelle épidémie de pathologies mentales qui affligent le monde contemporain.

Mots clés: Psychopathologie, écologie, mondaine, Merleau-Ponty

Versão inicial recebida em julho de 2004

Versão revisada recebida em dezembro de 2004 